\title{
Evaluating an International Investment Court for International Investment Disputes Under European Union's Proposal
}

\author{
Ahmed Arafa ${ }^{1} \&$ Guo Dexiang ${ }^{1}$ \\ ${ }^{1}$ School of Law, Zhengzhou University, Zhengzhou, China \\ Correspondence: Guo Dexiang, Professor at School of Law, Zhengzhou University, Zhengzhou, China. E-mail: \\ dexiangguo@sina.com
}

Received: November 7, 2020

Accepted: December 23, 2020

Online Published: December 29, 2020

doi:10.5539/jpl.v14n2p74

URL: https://doi.org/10.5539/jpl.v14n2p74

\begin{abstract}
Berserk resentment of the existing framework regulating the international investment protection system and the operating of investment tribunals have direct to a prevalent perception that there is an immediate need for reform. This is especially pronounced having to do with Investor-State dispute settlement (ISDS), where there is an overall perception that it is not anything but an unfair and unbiased arbitration system available to decide disputes between states and foreign investors. Therefore, ISDS has been obtained a reputation for being non-transparent, one-sided, and contradictory in all decisions made by ISDS tribunals. The European Union (EU) has responded to this need, by proposing an international investment court; in this research, an attempt is making to look at this court, according to the European Union's proposal. Moreover, the research explores the potential in creating this international investment court since a system can be drastically altered. However, some criticism can be addressed by international investment courts. However, specific steps can be taken to improve the international community's investor-state dispute settlement system by re-valuating all the objectives and goals to solve international investment disputes.
\end{abstract}

Keywords: Investor-State dispute settlement tribunals (ISDS), International Investment court (IIC), International Investment Law (IIL)

\section{Introduction}

Investor-State Dispute Settlement (ISDS) provisions have been for decades, an essential part of international investment agreements (IIAs) (Gaukrodger, D., \& Gordon, K, 2012). Identifying the necessitate for impartial, autonomous, and effective dispute resolution, IIAs respond to domestic shortcomings and give foreign investors the right to file a lawsuit before international arbitration (IA) against the host state for non-conformity with investment regulations. International arbitration was recognized and used to depoliticize investment disputes and strengthening the rule of law in investor-state relations (Shihata, I. F, 1986). Nevertheless, over the past decade due to the sharp increase in arbitrations of investment treaties, many concerns have come into focus with the existing ISDS regime, (Brower, C. N., \& Schill, S. W, 2008) providing increase to extensive demands for reform (UNCITRL, 2017 \& 2018). Frequent concerns include discrepancies in decision-making, inadequate respect by some arbitral tribunals for the right of the host-state to legalize in the interpretation of IIAs, allegations of bias of the legislation in the favor of foreign investors (FI), concerns about arbitrators' lack of independence and impartiality, limited mechanisms for control and regulating arbitral tribunals and ensuring the rightness of their decisions, and rising investment disputes settlement expenses (Off. U.S. "Trade Representative", Year 2015 \& EVANS, Year 2015).

Instead of the several ad-Hoc tribunals that were independently formed for each investment dispute, a permanent tribunal was introduced in the past as a reformation to overcome the huge wave of ISDS criticisms (Grisel, F., \& Schultz, T, 2015). This idea rose on periodically occasions while negotiating the important mega-regional investment treaties, such as the Comprehensive Economic and Trade Agreement (CETA) between the European Union (EU) and Canada, the Transatlantic Trade, and Investment Partnership (TTIP) between EU and United States (US), and the TransPacific Partnership (TPP) (Schill, S, 2015). Thus, CETA went to establish a Permanent Investment Court (PIC), known as the Investment Court System (ICS) (European Commission, CETA explained).

It is necessary to take into consideration the original intent and vision of ISDS to evaluate a permanent ISDS Tribunal solution. Throughout human history, foreign investment has been an economic fact (Collins, D, 2016). 
Moreover, Independent forums, such as international investment tribunals, have been established to settle disputes for this practice to suit and fit into the features of the new universal economy. It played an immensely significant role in establishing a middle ground between protecting state sovereignty and investor while selecting neither the host nor the investor-state as an arbitration site (Collins, D, 2016). Eventually, it helped make investors feel safe, who might on the other side be pressured to make claims to domestic investment courts, leading to possible prejudice (Brower, C. N., \& Schill, S. W, 2008). This tribunal also assured private investors that additional rights would be possessed by them when the countries they will be investing in will have lower legal standards than their own country (Koeth, W, 2016). In theory, it can be argued that it helped create reciprocal and fair business relationships due to the tribunal's existence facilitated international investment. It can be called quite advantageous for both the economy of the host state and investor. ISDS reforms' discussion poses a severe question in historical context: have global concerns and priorities of every country changed over time, and can ISDS be called a broken system? Can any changes play their role in improving the ISDS system by serving the original purpose?

However, does the permanent investment tribunal can play its role in thwarting all principles and rules envisaged for ISDS at its establishment. More significantly, it thwarts the balance between state sovereignty's protection and investors' recognition as a private entity that is entirely autonomous. In addition to this, such comments will be immensely helpful in exploring the drawbacks and potential benefits to reform ISDS. Thus, the research will address these questions; First, will give a short description of the EU's ICS and MIC, the two major proposed permanent courts for ISDS cases, while describing how these bodies operate compared to conventional tribunals. In addition, it will concentrate on three major concerns, including consistency, legitimacy, and transparency, that need to be addressed by a permanent investment court. The current research would also explore why such areas are called problematic by critics. The paper would also explore whether or not such permanent investment tribunals would solve issues by following the original purpose of ISDS.

\section{Proposed Permanent ISDS Mechanisms by European Union}

\subsection{The International Court System (ICS)}

CETA was provisionally adopted on 21-11-2017, but the national parliaments must approve it, of the Member States, before it is fully implemented (European Commission, CETA explained). It may take some time because several member organizations such as Belgium need to wait for CETA to be approved by provincial legislatures (Ross, 2018). They did not include ICS as a CETA part which is currently temporarily in effect; however, it has played its part as the center of discussion on whether permanent investment courts could effectively contribute to the dispute resolution process (European Commission, CETA explained). CETA's goal is established as follows:

"Attain the highest expectations of industry and citizens for a more transparent, fairer, and institutionalized system of resolving investment disputes and make sure the top level of protection for investors. Therefore, fully protecting the right of governments to pursue and regulate legal public policy aims being as the protection of safety, health, or the environment" (European Commission, 2016).

Nevertheless, ICS will work like other international courts by appointing permanent professional judges according to the required qualifications, (European Commission, 2016) and this differs from the current traditional temporary tribunals (DECHERT LLP, 2016). Therefore, judges would then be randomly assigned to cases to aid with impartiality (European Commission, 2016). On the one side, ICS will work on two levels (primary and appeal), (DECHERT LLP, 2016) On the other side, transparency will be the focus of the ICS, and all trials and proceedings would be available to the public and all court documents and resolutions will be posted on the United Nations (UN) website (European Commission, 2016).

\subsection{The Multilateral Investment Court (MIC)}

Foreign direct investment (FDI) is now the responsibility of the EU, as specified in the Treaty of Lisbon (TOL), it does not fall under member states' responsibility, and this means that, essentially, all agreements on international protection between the third-party countries and European Union (EU) would replace identical bilateral agreements between the Member States and the countries of third parties. (European Union, 2007). It is because international agreements' significant portion is represented by it. EU attempted to create an effective, updated, and accurate model for dispute resolution (Advisory council on international Affairs, 2015). In 2015, First, the European Commission sought to ISDS reforms through negotiations on the inclusion of the ICS in bilateral agreements with the EU. Then they started working on MIC simultaneously (Council of the EU, 2018). The purpose of MIC is to create a permanent forum for deciding on various investment disputes, which will play their part in bringing jointly some lineaments of domestic and international courts (O'Connor \&amp; Aquilini, 2017). Such multilateral investment courts can be regarded as intense reactions to some serious concerns regarding ISDS mechanisms, inclusive of "its lack of transparency, legitimacy, and consistency (Council of the EU, 2018)." The 
MIC is described by the European Commission (UC) as an independent, permanent, comprehensive, predictable, transparent, and cost-effective court (European Commission State of The Union, 2017). Cases at both an appellate level and a trial court will be effectively empowered to enforce its decisions (European Commission, 2016).

\section{The Main Criticisms to be Resolved by the Permanent Court}

Critics have raised three major concerns regarding the current status of the ISDS system, which includes consistency, transparency, and legitimacy. This part will attempt by examining contours as well as bounds of every concern, which conclude by assessing whether or not a permanent court system will be responding to such concerns. The analysis in this study would help expose permanent investment courts proposed by the EU as not very efficient and a long-term solution, which plays its role in diverging from the ISDS's original aims, which are considered highly essential for its success (ACERIS Law LLC, 2017). It has been said that "their formation is a distraction from factual reform efforts; at worst, it has the potential to make some additional problems that could damage global investment overall."

\subsection{The Legitimacy Concern}

Critics of ISDS mechanisms have raised concern about its legitimacy, which includes: (1) the system is considered as a bypass to domestic court; (2) tribunals are pro-investor;

(3) there is biasness in arbitrators and (4) national regulation is intensely haunted by it because there is a fear of future liability among states. This study would discuss such legitimacy problems in detail while analyzing whether or not a permanent court and such reforms provide greater legitimacy can be introduced and implemented in the existing framework without the need to create a new permanent judicial body.

\subsubsection{Bypassing Domestic Courts to International Arbitration Tribunals}

International investment disputes vary from the conventional international law paradigm in which only States may make claims under international law. In comparison to sovereignty countries, private companies do not require their home state's permission to sue another host state in ISDS proceedings (Vadi, V, 2016). Due to this reality, several critics see ISDS as a means to circumventing domestic law and national courts (EFILA, 2015). Whereas certain host countries request claimants to pursue every national solution until an international court assumes jurisdiction over this state, some countries do not require national solutions in investment agreements (Collins, D, 2016). It is the State's general responsibility to incorporate such a clause, and these clauses are not popular in new international investment agreements (Collins, D, 2016). This bypass therefore enables foreign investors to have more legal rights than domestic investors, who do not typically have access to an international platform when they are adversely affected by national regulations (EFILA, 2015).

To several investors fearing prejudice in domestic courts, a bypass is necessary. To address this concern, before ISDS proceedings are initiated, individual states could request a case to initiate at the local scale. Prior to pursuing an ISDS resolution, special chambers in appellate courts (AC) or even supreme courts (SC) staffed by ordinary judges could be a suitable venue for domestic redress (Schill, S, 2015). As a consequence, instead of seeing the ISDS regime as moving beyond domestic courts, ISDS courts can operate in parallel with national courts (DECHERT LLP, 2016). Alternatively, investors could be required to obtain consent through their states by first submitting the conflict to a preliminary governmental investigation. Hence, It may be a way to ensure legal claims and thus legitimacy as a whole by making the investor-state government serve as a gatekeeper (Franck, S. D, 2004).

\subsubsection{Tribunals Are Pro-Investors}

Many who sight ISDS as a bypass of national courts argue that there are pro-investor biases in these courts, which play an essential role in hindering their legitimacy (Subedi, S. 2016). Moreover, the current system's proponents refer to numbers. Member states use ISDS forums, but there can be an immense increase in their use over time (ICSID. 2018). Therefore, the rising and continuing usage of ISDS tribunals in the international sphere reflects its alleged legitimacy. Hence, the widespread impression of pro-investor biases in these courts has no support when verified in ISDS data (Subedi, S. 2016). It is shown by statistical evidence that states consistently win more cases in arbitral proceedings than investors. Between 1986-2016, 495 cases were brought to different investor tribunals; 27 percent of cases favored investors, while 36 percent were in favor of the state, and other cases were dismissed (Ross, A. 2018). In addition to this, international agreements are made for fostering a relationship, which can be mutually beneficial for all.

"The promotion and protection of foreign investment are mainly provided, not only for the personal benefit of foreign investors who benefit from the protections in question. But there are placed in place in response to the general public interest of States in rising foreign investment flows. Moreover, for taking advantage of the benefits that foreign investment can bring, such as the increase in economic competitiveness, the creation of employment, 
transfer of technology, and tax income. This interest constitutes a community interest for the collection of all host States, that is shared by all states participating in the IIL system" (W. Schill, S., \& Djanic, V, 2016).

\subsubsection{ISDS Arbitrators are biased}

At present, there is no one accepted method of appointing arbitrators in ISDS; rather, it relies on the relevant laws as well as treaties regulating the conflict (Brower, C. N., \& Schill, S. W. 2008). Consequently, it is argued by the critics that arbitrators cannot always be quality, are biased, and may lack diversity sometimes. One of the major concerns is that there is no accountability of arbitrators in ad hoc proceedings, and they are appointed by parties (Giorgetti, C, 2013). Although many view accountability as a force that counters independence, it has been argued that there is a need for accountability for ensuring impartiality. Critics believe that self-interest is the main focus of arbitrators because their living is based on which they are paid. Therefore, self-interest plays its role in leading arbitrators to decide a way favorable to their specific parties (Kohler, G., \& Potestà, M). This alleged bias is also illustrated by the reality that arbitrators are permitted to serve as counsel in procedures that take place between their appointments as arbitrators (The Multilateral Investment Court 2017). Often called "double hatting," an arbitrator can make a ruling on the matter in one case, and then argues the same argument in another case as a counsel (Aren, S. 2016).

To guarantee the arbitrators are not pro-investors, ICS contains certain features. For example, the ICS includes a code of conduct instead of only a requirement that arbitrators are impartial under the treaty and regulations of the arbitral body (Kohler, G., \& Potestà, M). In addition to this, judges' permanency exists in the ICS for minimizing bias. Judges may not, in any existing or new dispute under any agreement, serve as attorney or witnesses or as party-appointed experts (Art. 8.31 of CETA). However, it can be contended that these solutions cannot correctly fix legitimacy issues. Though in any other case, while ICS judges might not eligible to serve as attorney in any other ISDS case, they might keep working as private attorneys beyond international investment treaties. As a result, there would be fewer conflicts of interest because of this, which does not totally eradicate them (Art. 8.31 of CETA). Unfortunately, completely removing biases from any system is impossible. However, it cannot be called wholly accurate, and the significance of ISDS cannot be ignored in the present international law. This irony has been nicely summed up the following way:

"The ISDS supporters doubted the conceptualization of the latest system. It is arguing that it would be based on states' aptitudes to control the system, which means that the state would appoint all judges. It would diminish identical legitimacy and eliminate any control from the investors that the promoters of the court system were keen to protect" (Aren, S. 2016).

Usually, the primary concern of arbitrators is all about the maintenance of an impartial reputation. Additionally, arbitrators are checked frequently by public observation. Arbitrators who do not expect to be impartial and being objective would be regarded adversely by the relevant community. Which is likely to greatly influence the career of an arbitrator (Brower, C. N., \& Schill, S. W. 2008). Furthermore, many ISDS tribunals focus upon more robust safeguards that help save professional reputation from destruction, if an arbitrator is found objective or act in a biased manner, there are some rules which exist to remove those arbitrators (Franck, S. D. 2004). Many arbitral institution's Statistics have shown that challenges to arbitrators have increased over time (Ma, W. J. M, 2012). Arbitrator Misconduct includes independence, qualification, lack of impartiality, or fitness (Koch, C, 2003). such challenges can be considered a valid ground in order to challenge the arbitral award itself (Franck, S. D. 2004). The International Centre for Settlement of Investment Disputes (ICSID) is known as an establishment that plays its role in providing services of ad hoc arbitration and helping to prevent biases.

Consequently, an arbitrator's disqualification is allowed if the arbitrators belong to the host state or even possess the investor's nationality (ICSID 2006). In order to prevent frivolous disqualification arguments, objectivity can be seen in the relevant legal criteria "It is based on how a fair 3rd party judges the facts" instead of the personal opinions of the party (ICSID Disqualification of Arbitrators).

There can be an enhancement of the ISDS system by removal procedure updates; it is regarded as an ad hoc system is the most important aspect where parties select arbitrators (Brower, C. N., \& Schill, S. W. 2008). In addition to this, the proceeding's voluntariness is reinforced by allowing parties to select their arbitrator, which dramatically reflects ISDS' nature, which derives from both parties' intentional choice to enter into an investment relationship (ICSID. n.d.). Giving power over the appointment of arbitrators to both parties allows the parties more willing to use ISDS bodies and to abide with the judgments made. Appointments also protect state sovereignty by enabling states to appoint candidates that support their view of the interpretation of treaties (Brower, C. N., \& Schill, S. W. 2008).

Moreover, even when bringing cases to the ICJ, States can select an ad hoc judge if there is not already working a 
judge of that states' Nationality sitting in court (Brower, C. N., \& Schill, S. W. 2008). It reflects the general compliance to respect the variety of states in international procedures. Tribunals should reinforce the dismissal and selection techniques for an arbitrator rather than stripping the state and investors of the chance to pick.

\subsubsection{The Threat of Litigation}

The main issue of ISDS criticism is Legitimacy, and concerns that investment treaties favor investors' interest over states' competing interests (Brower, C. N., \& Schill, S. W. 2008). Immunity is waived by states while submitting to the international tribunal under investment treaties over issues of national regulation (Maupin, J. A, 2013). Therefore, states do not only claim that there are impartial international investment tribunals, but there are many who argue that there is serious interference of pro-investor biases with state sovereignty. In return, it dramatically hinders a liability of a state in terms of passing legislation for the welfare of its citizen (EFILA, 2015). National legislation's drafters attempt in terms of striking a balance between giving respect to the desire of the host state and foreign investors' expectations for regulating without liability (Giest, A, 2017). This regulatory chill can dramatically influence the lives of the citizens of the host state, which makes ISDS unpopular. ISDS is also known as "a massive Trojan horse" by Yannick Jadot, European Parliament Green Party spokesman. He explained ISDS in such a way that; "It can be used by many multinational corporations to whittle away European Union (EU) regulations and standards across a series of policies from the environment to food safety to social protection" (Release, P., 2014). The Economist, a British publication stated the same notion:

"If you required persuading the public that international trade agreements (ITA's) are an approach to let multinational companies acquire wealthy at the expenditure of common person. At this stage, what to do is: offer foreign firms an appropriate right to apply to a secretive tribunal of greatly remunerated corporate attorneys for reimbursement. Whenever a government enacts legislation to discourage to do smoking, prevent a nuclear catastrophe, or protect the environment. Nevertheless, that is specifically what thousands of investment and trade treaties during the last half-century have ended, through an appropriate process known as "Investor-state dispute settlement ISDS" (Investor-state dispute settlement 2014)."

However, it is necessary to acknowledge the limitations, though, since they do exist. Investors cannot challenge regulatory amendments carte blanche; they can launch proceedings just if the host state has assured to abstain from those specific changes (Brower, C. N., \& Schill, S. W. 2008). In addition to this, state regulation is consistently respected by ISDS tribunals when it comes to public policy. For instance, when public health is in danger, ISDS tribunals need to respect state policies (Philip Morris v. Oriental Republic of Uruguay 2016). The recent case of Philip Morris vs. Uruguay has provided the ISDS tribunal's more remarkable example. Concerning legitimate and fair state regulation. Investor "Philip Morris" in Feb 2010, blamed damage done by Uruguay under packaging legislation, which prohibited special packaging for Marlboro Gold and Marlboro Red (Philip Morris v. Oriental Republic of Uruguay 2016). The legislation was proposed and passed for the health of the public. It was also asked to put specific pictures illustrating that smoking is injurious to health. Philp Morris challenged the national legislation since he claimed that it has dramatically influenced investment as it has devalued in the country. It was demanded by the company that there should be repealing of smoking regulations, or they should not be applied to them, which would compensate for their damage (Philip Morris v. Oriental Republic of Uruguay, 2016).

ICSID dismissed the claim of Philip on 8 July 2016 (Ferrand, G, 2016). They ordered Philip Morris to pay seven million dollars to Uruguay as a refund. ICSID recognized health protection measures since the main objective of those aims was to protect the health of Uruguay people as an "exercise of the legitimate power of a sovereign country (Ferrand, G. 2016)." Same like this, the 1st investor-state dispute was fetched by Philip Morris in 2011 vs. Australia (Tobacco plain packaging-investor-state arbitration, 2011). Philip Morris Asia challenged the "Australian Tobacco Plain Packaging Act" was challenged by the company while arguing that Australian tobacco legislation restricted companies in terms of branding or showing their logos on the packaging (Ritwik, A, 2013). However, the tribunal unsuccessful to reach the issue's merits (Hepburn, J., \& Nottage, L. R, 2017). It was observed, however, that Philip Morris Asia's claim was a misuse of the operation after Philip Morris Asia acquired an Australian company for the sole purpose of acquiring standing to contest Australia's tobacco plain packaging legislation (Tobacco plain packaging - investor-state arbitration, 2011). it can be said that this plays an important role in supporting the notion that ISDS is an appropriate forum, it does not pave the way for investors to take the state's advantage by abusing the process and controlling its regulating power.

\subsection{The Consistency Concern}

International investment law, unlike the World Trade Organisation (WTO) or the UN, has no hierarchy, no single organizing agency and no historical genesis or originating document recognized by all (Maupin, J. A, 2013). Rather, it comprises of conflicting international bilateral and regional treaties, and an undisclosed number of domestic 
laws aimed at promoting economic growth through appealing and securing foreign investments within the sovereign territories of individual host states (Maeupin, J. A, 2013). It has been challenging to provide a consistent body of investment law, in part because ISDS contains aspects of both private commercial arbitration and public international law.

It cannot be denied that there are significant contradictions in international investment arbitration, but it is not the rule. Argentina has suffered from repeated inconsistent ISDS decisions directly during its participation in ICSID arbitration. Following the onset of its worst financial crisis in 2001(Lopez, O, 2014) and as a result of this crisis, a package of emergency legislation was implemented which, in turn, led to a significant change in the circumstances in which investors had to function. Thereby, led to many cases from ISDS against the country (Goodman, C. L, 2007). Although many of these cases were addressed precisely the same post-crisis emergency laws. investors, on the one side, placed out very similar claims in these cases, and Argentina utilized a nearly similar set of defences. On the other side, the outcomes of the ICSID were remarkably different depending on different interpretations of the Non-Precluded Measures (NPM) clauses (Lavopa, F, 2015).

Moreover, Critics claim that the formation of a permanent courts' regime will encourage consistency in a manner that has not been created by ad hoc tribunals. Thus, dispute settlement has a central role to become stable the expectations of foreign investors (FI's) and facilitates them to respond opportunistic behaviour by the host state, like as unsupported interferences with the investor's economic rights (Brower, C. N., \& Schill, S. W. 2008). There is no stare decisis in international investment law disputes, though technically speaking; a permanent tribunal would have a greater probability of reaching more clear judgments that are more consistent with one another. A permanent court may not only be viewed as more legitimate, but it could also help establish investment law predictability, a positive for both states and investors (Schill, S, 2015).

Resolving the problem of consistency, however, comes with its own collection of challenges and concerns. Creating a permanent court to address the problem of inconsistency may have an injurious effect on the protection of state sovereignty. For many investors, the ad-hoc nature of the ISDS system is essential. "Apart from the query is regarding arbitrators, "who sits, appoint and elects them. The permanent institutions may exhibit stronger dynamics in expanding their jurisprudential powers than a system of one-off the arbitral tribunals (Schill, S, 2015)." While a permanent investment entity can start to build consistent investment law, certain rules that may evolve are likely to impact states differently. Under this case, certain states may arise as "decision-makers," while other states do not agree with the adjustments, they see taking place, shifting the operation away from a democratic effect (Schill, S, 2015). While consistency may be generated by a permanent court, it does not necessarily contribute to the development of generally agreed and just standards. Consistency alone, which theoretically might be accomplished with the existing regime, the soundness of the law produced would not fix. Consistency does not constitute a silver bullet. It is only useful if the contents of the law are sound (Grisel, F., \& Schultz, T, 2015). The formation of a permanent court employing permanent judges and establishing a consistent body of law is likely to be harmed state sovereignty rather than support.

\subsection{The Transparency Concern}

Although transparency is a substantial issue in the ISDS proceedings, all aspects of international investments are not completely in the dark to the public. Major multilateral conventions, such as the ICSID, as well as numerous bilateral and regional treaties, are issues of public record (Maupin, J. A, 2013). In a certain issue, however, accessibility to the treaty text varies greatly from privacy to the internal workings of the tribunal. Published information about the existence of a specific dispute, the dispute procedure, the substantive aspects of the case and the outcomes can be restricted in investment dispute proceedings (European Commission. 2017). Hearings may be held in camera, the documents and records presented by the parties keep private in principle. Additionally, the award granted can only be published if the parties so wish (Vadi, V, 2016). However, it is crucial to remember that significant progress and improvement has been made overall in the field of transparency and many problems have also been addressed (Maupin, J. A, 2013).

Although the ISDS presently does not have a general secrecy obligation, there is an assumption of respect for the principles of confidentiality and privacy (EFILA, 2015). Inserting obligatory transparency into investment cases would defeat the principle of secrecy that is significant to investors. Through ISDS "confidential and neutral arbitration is one of the key pillars of international investment law, which are recognized by every major capital importing and exporting nation in the world". Compulsory secrecy could dramatically tip the balance imagined for ISDS by not respecting and disregarding the investor as an independent private entity.

Therefore, promoting and encouraging, rather than requiring, transparency is likely the best solution, and there are many reasons why transparency in conflicts should be promoted by the international community. Transparent 
procedures have the possibility to enhance the quality of democratic circulation about risk and its regulation and control, especially in sensitive areas such as health and the environment, by reinforcing public access to information and participation (Magnuson, W. J, 2010). Designing the ISDS rules to allow as much transparency as possible is a solution that preserves the equilibrium between the responsibility of a state to its citizens and the right to business secrecy of a private investor.

At present, the level of transparency in proceedings can be adapted by the parties in the ICSID. The Contracting Parties may decide about what information and documents they want to hold private, and may agree that the publication of documents can be regarded on a case-by-case basis. Once the parties negotiate and agree to a secrecy level for a specific proceeding, the agreement is normally signed and approved in a formal order by the tribunal. "The agreement may permit either party to designate documents as confidential, it's maybe in a part or whole," or to allow particular parts of the document to be revised and redacted before publication for the public (ICSID Confidentiality and Transparency). The Contracting Parties may also enable public access to hearings in person or by way of web or video transmission (ICSID Convention Arbitration Rules). If parties use this option, additional steps and measures may be taken to protect privileged information and details by suspending parts of the hearing from broadcasting (ICSID, Confidentiality and Transparency).

The creation and development of the UNCITRAL Transparency Rules, which are automatically applied to present investment agreements, is another solution recently adopted by the UNCITRAL. In 2014, UNCITRAL reviewed the investor-state arbitration transparency requirements and established these updated Rules (UNCITRAL Rules). The Rules invert the assumption of historical secrecy, but a goal to establish a balance by being open, thus safeguarding secret business information and national interests (EFILA, 2015). The Rules exclusively apply to investor-state claims resulting from treaties adopted after the enactment of the revised Rules on 1 April 2014 "unless the parties opt-out", however, the Rules can be adopted by treaties negotiated prior to their formation if the parties agree, or proactively amend the agreement (UNCITRAL Rules). The new rules alter procedures in significant ways, for example, by requiring publication of rulings and some documents and opening procedures to the public unless otherwise determined by the tribunal (UNCITRAL Rules). The UN has adopted the Rules at the Convention on Transparency in Treaty-Based Investor-State Arbitration (EFILA, 2015). In general, widely steps have been taken to increase and promote transparency in ISDS proceedings, rendering this case less relevant than it has been in the past.

\section{Conclusion}

Investor-state arbitration has emerged as international investment agreements' standard feature since the 1980s since it also plays a significant role in assessing the nature of ISDS tribunals in the global community of today's world. Many solutions range from state-to-state arbitration to a permanent investment court has been proposed. However, there is a potential in the creation of a permanent investment court since a system can be drastically altered. However, some criticism can be addressed by permanent investment courts. However, it also disrupts ISDS' key objectives which include the balance between investors' recognition and state sovereignty's protection as an independent private entity. However, ISDS System is broken, the international community needs to re-evaluate all the objectives and goals in order to solve investment disputes. There should be proper implementation of it. ISDS's original purpose is still honoured in today's world. Trading a longstanding ISDS system would be highly unwise because it is built to respect international investment's foundational elements.

In addition, the conclusion of international investment agreements (IIA's) and the adjudication and filing of investor-state disputes being continuous, many significant issues arose in this last year and a half. One first issue is a concern to the apparent consensus on the requirement to reform international investment law, a factor particularly declared in the context of investor-state dispute settlement. In most recent years the debate on reform was determined to require rebalancing investment agreements, and essential achievements have been made in this respect. The newest developments demonstrate a shift of focus to getting better investment dispute settlement. Remarkable among others is the suggestion to set up a permanent investment court, coming not only from policymakers but also from academia as well, including the European Union (EU). Nevertheless, the European Commission proposed an effective mechanism to settle down disputes, and this mechanism would work successfully, it would go a long way successfully to resolve investment disputes, but the importance of ISDS still cannot be denied. However, still, this proposal deserves attention and consideration. If there is an intention of member states to establish an investment court that would be able to handle cases, it would be overwhelming. There is one additional part of this trouble that desires to be measured. The ICSID was initially recognized to facilitate capital flow and promote investments. Without employing the cumbersome machinery of diplomatic protection, it was considered to be in service of business operations and tasked to give efficient relief for disputes. To the interests of the investors and the States, the ICSID is considered as being subordinated. On the other side, 
the International Investment Court (IIC) is a place to be hierarchically above investors and the States. With regards to authoritarian powers at this stake, it can be seen as a demonstration of accumulating supremacy in a single institution. The synthesis of 2 procedures into one manifestly adds to that impression. If the ICSID was violently inspected, why should not the International Investment Court be? With the introduction of amendments proposed by critics because in reality the formation of the ICS could be wrong for existing multilateral agreements, like the ICSID agreement, and would mean the possible amendment of other multilateral agreements like the New York agreement.

\section{References}

Aceris Law LLC. (2017, 7 January). From International Investment Arbitration to an Investment Court System. Retrieved October 30, 2020, from https://perma.cc/CD5Z-3DMZ

Advisory council on international Affairs. (2015, April). International Investment Dispute settlement from AD hoc arbitration to a permanent court. Retrieved October 29, 2020, from https://perma.cc/Z6S2-RU3M

Aren, S. (2016). Has the time come for the establishment of a permanent investment court? The 'ayes' have it: Arbitration Blog. Retrieved October 14, 2020, from https://perma.cc/4L4M-2LZM

Article 8.31 of CETA: Text of the Comprehensive Economic and Trade Agreement - Chapter eight: Investment. (2020, August 14). Retrieved October 30, 2020, from https://www.international.gc.ca/trade-commerce/tradeagreements-accords-commerciaux/agr-acc/ceta-aecg/text-texte/08.aspx?lang=eng

Bernasconi-Osterwalder, N., \& Mann, H. (2014). A Response to the European Commission's December 2013 Document "Investment Provisions in the EU-Canada Free Trade Agreement (CETA)". Int Inst Sustain Dev.

Brower, C. N., \& Schill, S. W. (2008). Is arbitration a threat or a boom to the legitimacy of International investment law. Chi. J. Int'l L., 9, 471.

Brussels. (2018). Commission welcomes adoption of negotiating directives for a multilateral investment court. Retrieved October 14, 2020, from https://trade.ec.europa.eu/doclib/press/index.cfm?id=1819\&amp;title=Commission-welcomes-adoption-ofnegotiating-directives-for-a-multilateral-investment-court

CETA explained - Trade - European Commission. (2018, 21 September). Retrieved October 29, 2020, from https://perma.cc/A6CE-A9BT

Collins, D. (2016). An Introduction to International Investment Law. Cambridge University Press. https://doi.org/10.1017/CBO9781316675687

Council of the EU. (2018, 20 March). Multilateral investment court: Council gives mandate to the commission to open negotiations. Retrieved October 30, 2020, from https://www.consilium.europa.eu/en/press/pressreleases/2018/03/20/multilateral-investment-court-council-gives-mandate-to-the-commission-to-opennegotiations/

DECHERT LLP. (2016, March). The EU succeeds in establishing a permanent investment court in its trade treaties with Canada and Vietnam: A Legal Update from Dechert's International Arbitration Group. Retrieved from https://perma.cc/DVW3-5PV5

EFILA. (2015, May 17). A response to the criticism against ISDS. https://doi.org/10.1144/geosci2020-081

European Commission State of The Union. (2017). A Multilateral Investment Court: A New System for Resolving Disputes Between Foreign Investors and States in A Fair and Efficient Way. Retrieved from https://trade.ec.europa.eu/doclib/docs/2017/september/tradoc_156042.pdf

European Commission. (2016). European Commission, Investment Provisions in The EU-Canada Free Trade Agreement (CETA). Retrieved October 29, 2020, from http://trade.ec.europa.eu/doclib/docs/2013/november/tradoc_151918.pdf

European Union. (2007). Treaty of Lisbon: Amending the Treaty on European Union and the Treaty Establishing the European Community. Office for Official Publications of the European Community.

Evans, C. (2015). ISDS: Important Questions and Answers [Web log post]. Retrieved from https://perma.cc/6YNVT7QA

Feldman, M. (2019). Connectivity and Decoupling: Belt and Road Dispute Resolution in a Fractured Trade Environment. https://doi.org/10.2139/ssrn.3451034

Ferrand, G. (2016). Alternative dispute resolution, International organizations, Marketing and advertising, 
Tobacco and smoking. Retrieved October 20, 2020, from https://perma.cc/49D3-U939

Franck, S. D. (2004). The Legitimacy Crisis in Investment Treaty Arbitration: Privatizing Public International Law through Inconsistent Decisions. Fordham L. Rev., 73, 1521.

Gaukrodger, D., \& Gordon, K. (2012). Investor-state dispute settlement: a scoping paper for the investment policy community. https://doi.org/10.2139/ssrn.2207366

Giest, A. (2017). Interpreting Public Interest Provisions in International Investment Treaties. Chi. J. Int'l L., 18, 321.

Giorgetti, C. (2013). Who decides who decides in international investment arbitration? U. Pa. J. Int'l L., 35, 431.

Goodman, C. L. (2007). Uncharted Waters: Financial Crisis and Enforcement of ICSID Awards in Argentina. U. Pa. J. Int'l Econ. L., 28, 449.

Grisel, F., \& Schultz, T. (2015). From Ad Hoc Tribunals to Permanent Courts: Three Examples.

Hepburn, J., \& Nottage, L. R. (2017). Case Note: Philip Morris Asia v Australia. The Journal of World Investment and Trade, 18(2), 307-319. https://doi.org/10.1163/22119000-12340038

Huang, J. (2018). Procedural Models to Upgrade BITs: China's Experience. Leiden Journal of International Law, 31(1), 93-115. https://doi.org/10.1017/S0922156517000516

I. (2016). Philip Morris Brands Sàrl, Oriental Republic of Uruguay, Award, ICSID Case No. ARB/10/7 (pp. 1-304, Rep.). ICSID.

ICSID Convention Arbitration Rules. (n.d.). Retrieved October 20, 2020, from http://icsidfiles.worldbank.org/icsid/icsid/StaticFiles/basicdoc/partF.htm

ICSID Convention, Regulations and Rules ICSID/15. (2006). Retrieved October 14, 2020, from https://perma.cc/5TZQ-V8EN

ICSID. (2018). The ICSID Caseload - Statistics (Issue 2018-1). Retrieved October 28, 2020, from https://perma.cc/9UTD-6ZRE

ICSID. (n.d.). Background Information on The International Centre For Settlement Of Investment Disputes (ICSID) (pp. 1-6, Rep.). Retrieved from https://perma.cc/3MCY-7ALQ

ICSID. (n.d.). Confidentiality and Transparency - ICSID Convention Arbitration. Retrieved October 20, 2020, from https://perma.cc/9TUF-D22X

ICSID. Disqualification of Arbitrators - Additional Facility Arbitration. (n.d.). Retrieved October 14, 2020, from https://perma.cc/4JQJ-BLA4

Investor-state dispute settlement the arbitration game. (2014). Retrieved from https://perma.cc/3BVJ-9UQE

Koch, C. (2003). Standards and procedures for disqualifying arbitrators. J. Int'l Arb., 20, 325.

Koeth, W. (2016). Can the Investment Court System (ICS) save TTIP and CETA? European Institute of Public Administration.

Kohler, G., \& Potestà, M. (n.d.). The Composition of a Multilateral Investment Court and of an Appeal Mechanism for Investment Awards (p. 15 November 2017, Publication No. CIDS Supplemental Report). CIDS-Geneva Center for International Dispute Settlement. Retrieved from http://www.uncitral.org/pdf/english/workinggroups/wg_3/CIDS_Supplemental_Report.pdf

Lavopa, F. (2015). Crisis, Emergency Measures, and the Failure of the ISDS System: The Case of Argentina. Views and Experiences from Developing Countries, 193.

Leary, M. C. (2018). Obtaining and Enforcing a Security Interest in Local Currency under

Lopez, O. (2014). Smart Move: Argentina to Leave the ICSID. Cornell International Law Journal Online, 1, 1-35. Retrieved from http://cornellilj.org/wp-content/uploads/2014 /01/Lopez-Smart-Move-Argentina-to-Leavethe-ICSID-final.pdf

Ma, W. J. M. (2012). Procedures for Challenging Arbitrators: Lessons for and from Taiwan. Contemp. Asia Arb. J., 5, 293.

Magnuson, W. J. (2010). WTO Jurisprudence and its Critiques: The Appellate Body's Anti-Constitutional Resistance. Harvard International Law Journal Online, 51(121).

Maupin, J. A. (2013). Transparency in international investment law: the good, the bad, and the murky. In A. Bianchi 
\& A. Peters (Eds.), Transparency in International Law. Cambridge University Press.

Off. U.S. Trade Representative. (2015, March). FACT SHEET: Investor-State Dispute Settlement (ISDS): United States Trade Representative. Retrieved October 29, 2020, from https://perma.cc/L7PN-DRCK

Payosova, T., Hufbauer, G. C., \& Schott, J. J. (2018). The dispute settlement crisis in the World Trade Organization: causes and cures (No. PB18-5).

RELEASE, P., \& In the European Parliament, T. E. (2014, 21 January). EU-US trade negotiations (TTIP). Retrieved October 19, 2020, from https://perma.cc/AYQ6-NUQD

Ritwik, A. (2013). Tobacco Packaging Arbitration and the State's Ability to Legislate. Harv. Int'l LJ, 54, 523.

Ross, A. (2018). "Fake news" - Brower blasts investment court proposal. Retrieved October 14, 2020, from https://globalarbitrationreview.com/article/1166223/-fake-news-brower-blasts-investment-court-proposal

Schill, S. (2015). Reforming investor-state dispute settlement (ISDS): conceptual framework and options for the way forward. by International Centre for Trade and Sustainable Development (ICTSD).

Shihata, I. F. (1986). Towards a greater depoliticization of investment disputes: the roles of ICSID and MIGA. ICSID review, 1(1), 1-25. https://doi.org/10.1093/icsidreview/1.1.1

Subedi, S. (2016). International Investment Law: Reconciling Policy and Principle.

Supnik, K. M. (2009). Making amends: Amending the ICSID convention to reconcile competing interests in international investment law. Duke Law Journal, 343-376.

The Multilateral Investment Court: A plausible attempt at reform, or cosmetic changes only?: News: LS Brussels. (2017). Retrieved October 14, 2020, from https://perma.cc/N3T2-G8NW

Tobacco plain packaging - investor-state arbitration, Philip Morris Asia Ltd. v. Commonwealth of Australia, PCA Case No. 2012-12, Notice of Arbitration. (2011, December 1). Retrieved October 20, 2020, from https://web.archive.org/web/20151129215745/http://www.ag.gov.au/tobaccoplainpackaging

UN. (2017). Working Group III: Investor-State Dispute Settlement Reform Commission on International Trade Law. Retrieved October 14, 2020, from https://uncitral.un.org/en/working_groups/3/investor-state

UNCITRAL Rules on Transparency in Treaty-based Investor-State Arbitration (pp. 1-20, Rep.). (2014). United Nations Commission on International Trade Law.

UNCITRL. (2017 \& 2018). Working Group III (Investor-State Dispute Settlement Reform) Thirty-fourth session and Thirty-Fifth Session: Possible reform of investor-State dispute settlement (ISDS). Retrieved from http://undocs.org/A/CN.9/WG.III/WP.142

UNCTAD. (2013). Number of international investment disputes mushroomed in 2012. Retrieved October 14, 2020, from https://unctad.org/en/pages/PressRelease.aspx?OriginalVersionID=120

United Nations. (2003). Report of the International Law Commission Fifty-fifth Session No. 10 (A/58/10). Retrieved from https://legal.un.org/ilc/documentation/english/reports/a_58_10.pdf

Vadi, V. (2016). Jus cogens in international investment law and arbitration. In Netherlands Yearbook of International Law 2015 (pp. 357-388). TMC Asser Press, The Hague. https://doi.org/10.1007/978-94-6265114-2_12

W. Schill, S., \& Djanic, V. (2016). International Investment Law and Community Interests. Soc'y of Int'l Econ. Law, Working Paper No. 1. https://doi.org/10.2139/ssrn.2799500

\section{Copyrights}

Copyright for this article is retained by the author(s), with first publication rights granted to the journal.

This is an open-access article distributed under the terms and conditions of the Creative Commons Attribution license (http://creativecommons.org/licenses/by/4.0/). 